\title{
Stepwise regulation of hole transport in DNA by control of triplex formation.
}

$\operatorname{AUTHOR}(S)$ :

Haruna, Ken-Ichi; lida, Haruka; Nishimoto, Sei-Ichi; Tanabe, Kazuhito

\section{CITATION:}

Haruna, Ken-Ichi ...[et al]. Stepwise regulation of hole transport in DNA by control of triplex formation.. Bioorganic \& medicinal chemistry 2013, 21(10): 2682-2686

\section{ISSUE DATE:}

2013-05-15

URL:

http://hdl.handle.net/2433/174059

\section{RIGHT:}

(C) 2013 Elsevier Ltd.; This is not the published version. Please cite only the published version.; この論文は出版社版でありません。引用の際に は出版社版をご確認ご利用ください。 


\title{
Stepwise Regulation of Hole Transport in DNA by Control of Triplex Formation
}

\author{
Ken-ichi Haruna, Haruka Iida, Sei-ichi Nishimoto and Kazuhito Tanabe* \\ Department of Energy and Hydrocarbon Chemistry, Graduate School of Engineering, \\ Kyoto University, Katsura Campus, Kyoto 615-8510, Japan \\ *corresponding author. Phone: +81-75-383-2505. FAX: +81-75-383-2504. \\ e-mail: tanabeka@scl.kyoto-u.ac.jp
}




\begin{abstract}
A functionality for regulating hole transport efficiency is a prerequisite for the utilization of DNA duplexes as nanodevices. Herein, we report the regulation of hole transport in anthraquinone-tethered DNA with dual triplex forming sites. Long-range photooxidation experiments showed that hole transport was effectively suppressed by the formation of triplex at low temperature, while it was recovered by dissociation to the duplex at higher temperature. Variation of temperature induced the formation and dissociation of the third strand at each triplex region individually, leading to the stepwise regulation of hole transport in DNA.
\end{abstract}

\title{
Key Words
}

Oligonucleotides, hole transport, triplex formation, photosensitization 


\section{Introduction}

There has been an increasing number of studies on long-distance hole transport in DNA, showing that a hole can migrate in a DNA duplex through continuous $\pi$-stacking. ${ }^{1-9}$ On the basis of this promising hole transport ability of DNA duplexes and the intrinsic fact that DNA forms highly organized structures, DNA is recognized as a potential candidate material for nanoscale molecular devices. ${ }^{10-18}$ To utilize DNA duplexes in this way, DNA duplexes need to be equipped with an on/off switching functionality of their hole transport efficiency. Recently, various attempts have been made to modulate the efficiency of hole transport in DNA using modified bases, ${ }^{19}$ structural changes of DNA, ${ }^{20,21}$ and binding of proteins ${ }^{22-25}$ or small molecules ${ }^{26}$ to DNA. However, there have been few reports describing reversible on/off regulation of hole transport in DNA duplex.

DNA triplexes are known to be the result of binding a polypyrimidine short strand to a DNA duplex using Hoogsteen hydrogen bonding, the formation of which can be regulated by external triggers such as salt concentration, $\mathrm{pH}$, and temperature. ${ }^{27-30}$ Furthermore, experiments on the oxidative cleavage of DNA and the photocurrent measurement of DNA on a gold electrode showed that a DNA triplex region involving a pyrimidine-purine-pyrimidine motif, such as $\mathrm{C}^{+} \cdot \mathrm{GC}$, has a lower hole transport capability because of its cationic environment and dissonant stacking interactions at the duplex-triplex junctions. ${ }^{31-35}$

Following on from these researches on hole transport properties of DNA triplex, we constructed a regulation system of hole transport in DNA by regulating the formation and dissociation of triplex. Figure 1A illustrates the concept of the regulation system, in which hole transport in an anthraquinone (AQ)-tethered duplex ${ }^{36}$ is regulated by the thermally-reversible association and dissociation of a short-strand oligodeoxynucleotide (ODN) with duplex DNA to form the triplex. Furthermore, regulation of hole transport by triplex formation and dissociation can be applied to stepwise regulation of hole transport in DNA with dual triplex regions (Figure 1B). 
(Figure 1)

\section{Results and Discussion}

\section{Design of AQ-tethered Triplex DNA.}

We selected the ODN base sequences so that they form $\mathrm{C}^{+} \cdot \mathrm{GC}$ triplex regions (Figure 2). To evaluate the long-distance hole transport in ODNs with partial triplex structural region, anthraquinone (AQ) chromophore as a photosensitizer for injection of a hole into DNA, was conjugated to the 5'-end of the ODN using a six-carbon linker, according to a previously reported method. ${ }^{26}$ Guanine doublets (GG) were arranged on the ${ }^{32} \mathrm{P}-5$ '-end labeled complementary strands of the AQ-tethered ODNs, because they are an efficient hole trapping site, and thus indicate the occurrence of hole transport by oxidative cleavage. ${ }^{37}$

(Figure 2)

\section{Evaluation of Hole Transport in DNA Possessing a Single Triplex Region.}

We initially evaluated the effect of triplex formation on hole transport in DNA duplexes possessing a single triplex region by monitoring oxidative cleavage of G doublets. Long-distance hole transport in Duplex I (AQ-ODN 1/ODN 2) and Triplex I (AQ-ODN 1/ODN 2/ODN 3) was induced by photosensitization of the AQ chromophore in AQ-ODN 1 in a sodium cacodylate buffer (pH 5.5) at $0{ }^{\circ} \mathrm{C}$. Three guanine doublets $\left(\mathrm{GG}_{1}, \mathrm{GG}_{2}\right.$, and $\left.\mathrm{GG}_{3}\right)$ were arranged in the ${ }^{32} \mathrm{P}-5$ ' -end labeled ODN 2 to indicate the occurrence of hole transport. The doublets $\mathrm{GG}_{1}$ and $\mathrm{GG}_{3}$ were located adjacent to, and away from the AQ chromophore at the duplex regions, respectively, while $\mathrm{GG}_{2}$ was in the triplex region of ODN 2. We evaluated the AQ-photosensitized ( $\lambda_{\mathrm{ex}}=365 \mathrm{~nm}$ ) oxidative cleavage of Duplex I and Triplex I to compare the efficiency of the long-distance hole transport. As shown in Figure 3, $\mathrm{GG}_{1}$ sites, which were proximal to the AQ chromophore, were cleaved strongly in both 
helices. ${ }^{38}$ It is noteworthy that cleavage at the $\mathrm{GG}_{3}$ doublets in Triplex I was reduced to more than one third of the intensity of Duplex I, indicating that partial formation of a triplex can interrupt hole transport beyond the triplex region. In addition, the cleavage at $\mathrm{GG}_{2}$ in Triplex II was also reduced. Although triplex formation may cause the suppression of hole transport to $G_{2}$, we could not rule out the possibility that a reduced degree of cleavage at the $G_{2}$ site in Triplex I was the result of reduced accessibility to oxygen and solvent caused by triplex formation. A photooxidative DNA cleavage at the $G$ residue occurs via the addition of oxygen and solvent to the $G$ radical cation intermediate; ${ }^{39,40}$ therefore, the cleavage at $\mathrm{GG}_{2}$ in Triplex II may be prevented by steric hindrance of the triplex-forming strand. In a separate experiment, upon $365 \mathrm{~nm}$ photoirradiation of a mixture of Duplex I and mismatched third-strand ODN 4, we detected efficient DNA cleavage at the $\mathrm{GG}_{3}$ site, which was of a similar magnitude to that observed for Duplex I alone (Figure S2). This result indicates that perfectly matched triplex formation is responsible for the suppression of hole transport through a DNA duplex.

(Figure 3)

\section{Evaluation of Hole Transport in DNA Possessing Dual Triplex Regions.}

We attempted to apply our system to regulate hole transport in DNA possessing dual triplex-forming regions. We prepared the AQ-tethered 46-mer Duplex II, Triplex II possessing 7-mer and 15-mer triplex regions, Triplex III possessing a 15-mer triplex region, and Triplex IV possessing a 7-mer triplex region (Figure 2). The hole transport at $0{ }^{\circ} \mathrm{C}$ was evaluated by oxidative cleavage at three $\mathrm{GG}$ sites $\left(\mathrm{GG}_{4}, \mathrm{GG}_{5}\right.$, and $\left.\mathrm{GG}_{6}\right)$, which were arranged to be located at the 3'- and 5'-side of each triplex region. As shown in Figure 4A, photoirradiation of Duplex II caused efficient cleavage at all GG sites, even at the $\mathrm{GG}_{6}$ doublet, indicating that the hole injected from the AQ chromophore arrived at the $\mathrm{GG}_{6}$ site. ${ }^{38}$ Addition of the 15-mer ODN 7 to Duplex II to form 
Triplex III dramatically reduced cleavage at the $\mathrm{GG}_{6}$ site, while the $\mathrm{GG}_{4}$ and $\mathrm{GG}_{5}$ sites were still cleaved. This result strongly suggests that hole transport between the $\mathrm{GG}_{5}$ and $\mathrm{GG}_{6}$ sites was suppressed effectively by the binding of ODN 7 to form a partial triplex, whereas the hole injected by the AQ photosensitizer could still migrate to the $\mathrm{GG}_{5}$ site. Furthermore, binding of ODN 8, or both ODN 7 and ODN 8, to form Triplex IV or II evidently reduced oxidative cleavage at GG 5 and $\mathrm{GG}_{6}$ sites, indicating that the hole transport between $\mathrm{GG}_{4}$ and $\mathrm{GG}_{6}$ was suppressed. Thus, hole transport could be properly regulated according to the position of the triplex region. In addition, we evaluated oxidative cleavage of Triplex II by photosensitization of 9,10-anthraquinone (Aq) and riboflavin ( $\mathrm{Ri}$ ) which were not linked to the ODN. As shown in Figure 4B, the cleavage pattern at the GG sites in Triplex II was similar to that in Duplex II. This result indicates that oxygen and solvent can access the guanine radical cations on the GG sites irrespective of triplex formation, resulting in an efficient strand cleavage at every GG site. In view of this, we concluded that the decrease in photosensitized cleavage at the $\mathrm{GG}_{5}$ and $\mathrm{GG}_{6}$ sites in the AQ-tethered triplex was almost certainly due to the decrease in hole transport efficiency at the triplex region.

(Figure 4)

\section{Regulation of Hole Transport in DNA Possessing Dual Triplex Regions by Thermal Duplex-Triplex Conversion.}

A further attempt was made to regulate hole transport through a DNA possessing dual triplex-forming sites by thermal conversion between the duplex and the triplex. We evaluated AQ-photosensitized oxidative cleavage of Duplex II and Triplex II to compare the efficiency of hole transport at different reaction temperatures. The reaction temperatures were chosen in the light of the thermal characteristics of Triplex II $\left(T_{\mathrm{m}}=13.6\right.$ and $31.1{ }^{\circ} \mathrm{C}$ for the dissociation of ODN 8 and ODN 7 from Triplex II, respectively). The temperature was changed from 0 to $20{ }^{\circ} \mathrm{C}$ for 
dissociation of ODN 8 from Triplex II, and then the sample was heated to $40{ }^{\circ} \mathrm{C}$ for further dissociation of ODN 7. The resulting duplex was cooled to $20{ }^{\circ} \mathrm{C}$ once again for binding of ODN 7 to form a partial triplex. The photoirradiation was conducted at each temperature to evaluate the stepwise regulation of hole transport in DNA. Figure 5A shows a representative gel picture, and Figure 5B shows the normalized increment of cleavage intensity at the $\mathrm{GG}_{6}$ site. Compared with the extent of cleavage at the $\mathrm{GG}_{4}$ site in Triplex II (lane 7 in Figure $5 \mathrm{~A}$ ), a weak cleavage at the $\mathrm{GG}_{5}$ and $\mathrm{GG}_{6}$ sites in Triplex II was observed at $0{ }^{\circ} \mathrm{C}$, indicating that hole transport was effectively suppressed by binding of both ODN 7 and ODN 8. Raising the reaction temperature from 0 to $20{ }^{\circ} \mathrm{C}$ induced a marked increase in cleavage at the $\mathrm{GG}_{5}$ sites in Triplex II (lane 8), but cleavage at $\mathrm{GG}_{6}$ was still suppressed (Figure 5B). In contrast, we confirmed that cleavage at the $\mathrm{GG}_{6}$ site in Duplex II increased at $20{ }^{\circ} \mathrm{C}$ (lanes 3) because of the temperature effect on long-range hole transport through the DNA duplex, consistent with previous reports. ${ }^{34,35,41}$ These results suggest that the hole injected from the AQ chromophore in Triplex II at $20^{\circ} \mathrm{C}$ could arrive at the $\mathrm{GG}_{5}$ sites as a result of the dissociation of ODN 8, whereas hole transport between the $\mathrm{GG}_{5}$ and $\mathrm{GG}_{6}$ sites was still suppressed by the binding of ODN 7 to form a partial triplex. Further raising the reaction temperature to $40{ }^{\circ} \mathrm{C}$ increased DNA cleavage at the $\mathrm{GG}_{6}$ site in Triplex II (lane 9 in Figure 5A and Figure 5B), ${ }^{17}$ indicating that the dissociation of ODN 7 to form a duplex allows for hole transport to the $\mathrm{GG}_{6}$ site. The inverse of this behavior was observed on lowering the reaction temperature from 40 to $20{ }^{\circ} \mathrm{C}$, showing a resuppression of DNA cleavage at the $\mathrm{GG}_{6}$ site in Triplex II (lane 10 in Figure 5A and Figure 5B). Thus, the rebinding of ODN 7 suppresses hole transport between the $\mathrm{GG}_{5}$ and $\mathrm{GG}_{6}$ sites. From these evidences, we conclude that hole transport in DNA possessing triplex regions at dual sites can be regulated individually using a change in temperature.

(Figure 5) 


\section{Conclusion}

We have demonstrated that reversible structural changes of DNA duplex into triplex are effective for regulating hole transport in DNA. AQ-photosensitized long-distance hole transport in DNA was suppressed to a large extent by triplex formation and was recovered by dissociation of the third strand. This regulation system can be expanded to a stepwise regulation of hole transport in DNA possessing dual triplex-forming sites. Thermal conversion of the duplex and triplex at each triplex-forming site resulted in a site-selective regulation of hole transport in DNA. Such a simple method for the regulation of hole transport would be applicable to on/off switching of DNA hole transport. Further investigations into the on/off regulation of hole transport in higher-order DNA structures are in progress.

\section{Supplementary data}

The data includes the autoradiogram of gel electrophoresis for the mixture of Duplex I and ODN 4 after photoirradiation and quantified cleavage data. 


\section{Experimental}

General. Gel electrophoresis was carried out on a Gibco BRL Model S2 apparatus. $\left[\gamma^{32} \mathrm{P}\right] \mathrm{ATP}$ (6000 Ci/mmol) was obtained from Amersham Bioscience. Unmodified DNA oligomers were purchased from Invitrogen. Anthraquinone tethered ODN (AQ-ODN 1 and AQ-ODN 4) was synthesized by the previously reported method. ${ }^{26}$ All aqueous solutions were prepared using purified water (YAMATO, WR600A).

$\boldsymbol{T}_{\mathbf{m}}$ Measurement. $2.5 \mu \mathrm{M}$ Solutions of the appropriate ODNs in the presence of $\mathrm{MgCl}_{2}$ in $10 \mathrm{mM}$ sodium cacodylate buffer ( $\mathrm{pH}$ 5.5) were prepared to determine the melting temperatures $\left(T_{\mathrm{m}}\right)$ of duplex and triplex. Melting curves were obtained by monitoring variation of the UV absorbance at $260 \mathrm{~nm}$ with elevating temperatures from $2{ }^{\circ} \mathrm{C}$ to $90{ }^{\circ} \mathrm{C}$ at a rate of $1{ }^{\circ} \mathrm{C} / \mathrm{min}$.

Preparation of 5'-32 P-End-Labeled ODNs. ODNs (400 pmol strand concentration) were labeled by phosphorylation with $4 \mu \mathrm{L}$ of $\left[\gamma^{32} \mathrm{P}\right] \mathrm{ATP}$ and $4 \mu \mathrm{L}$ of $\mathrm{T}_{4}$ polynucleotide kinase using standard procedures. The 5'-end-labeled ODNs were recovered by ethanol precipitation, further purified by 15\% nondenaturing gel electrophoresis, and then isolated by the crush and soak method.

\section{General Procedures for Photoinduced Cleavage of ${ }^{32}$ P-5'-End-Labeled ODN Hybridized with} AQ-ODN. Triplex samples were prepared in the presence of $2 \mathrm{mM} \mathrm{MgCl}_{2}$ in sodium cacodylate buffer ( $\mathrm{pH}$ 5.5) by hybridizing $1 \mu \mathrm{M}$ of AQ-ODN 1 or 5 with a mixture of their cold and radiolabeled complementary strand $(1 \mu \mathrm{M})$ and $5 \mu \mathrm{M}$ of the third strand (ODN 3 for Triplex I, ODN 7 for Triplex III, ODN 8 for Triplex IV, and both ODN 7 and ODN 8 for Triplex II). Duplex formation was achieved by heating the sample at $90{ }^{\circ} \mathrm{C}$ for $5 \mathrm{~min}$ and slowly cooling to room temperature. Triplex formation was achieved by cooling at $4{ }^{\circ} \mathrm{C}$ overnight after addition of the third strand to the duplex samples. The ${ }^{32} \mathrm{P}-5$ '-end-labeled duplex and triplex were irradiated at 365 
$\mathrm{nm}$ at given temperatures. In the experiment of regulation of hole transport, the reaction vessels were alternately transferred between different reaction temperatures. After irradiation, all reaction mixtures were precipitated with addition of $10 \mu \mathrm{L}$ of herring sperm DNA (1 mg/mL), $10 \mu \mathrm{L}$ of $3 \mathrm{M}$ sodium acetate and $800 \mu \mathrm{L}$ of ethanol. The precipitated DNA was washed with $100 \mu \mathrm{L}$ of $80 \%$ cold ethanol and dried in vacuo. The resulting DNA was resolved in $50 \mu \mathrm{L}$ of $10 \%$ piperidine (v/v), heated at $90{ }^{\circ} \mathrm{C}$ for $20 \mathrm{~min}$ and then concentrated. The radioactivity of the samples was assayed using an Aloka 1000 liquid scintillation counter, and the dried DNA pellets were resuspended in $80 \%$ formamide loading buffer (a solution of $80 \%$ formamide (v/v), $1 \mathrm{mM}$ EDTA, $0.1 \%$ xylene cyanol and $0.1 \%$ bromophenol blue). All reactions, along with the Maxam-Gilbert G+A sequencing reactions were heat-denatured at $90{ }^{\circ} \mathrm{C}$ for $3 \mathrm{~min}$ and quickly chilled on ice. The samples (1-2 $\mu \mathrm{L}$, $\left.2-5 \times 10^{3} \mathrm{cpm}\right)$ were loaded onto $15 \%$ of polyacrylamide/7 $\mathrm{M}$ urea sequencing gels, electrophoresed at $1900 \mathrm{~V}$ for $60 \mathrm{~min}$, transferred to a cassette and then stored at $-80{ }^{\circ} \mathrm{C}$ with Fuji X-ray film (RX-U). The gels were analyzed by autoradiography with the ATTO densitograph software library (version 3.0). The intensity of the spots resulting from piperidine treatment was determined by volume integration. 


\section{References and Notes}

(1) Meggers, E.; Michel-Beyerle, M. E.; Giese, B. J. Am. Chem. Soc. 1998, 120, 12950.

(2) Henderson, P. T.; Jones, D.; Hampikian, G.; Kan, Y. Z.; Schuster, G. B. Proc. Natl. Acad. Sci. U.S.A. 1999, 96, 8353.

(3) Nakatani, K.; Dohno, C.; Saito, I. J. Am. Chem. Soc. 1999, 121, 10854.

(4) Bixon, M.; Giese, B.; Wessely, S.; Langenbacher, T.; Michel-Beyerle, M. E.; Jortner, J. Proc. Natl. Acad. Sci. U.S.A. 1999, 96, 11713.

(5) Williams, T. T.; Dohno, C.; Stemp, E. D. A.; Barton, J. K. J. Am. Chem. Soc. 2004, 126, 8148.

(6) Osakada, Y.; Kawai, K.; Fujitsuka, M.; Majima, T. Proc. Natl. Acad. Sci. U.S.A. 2006, 103, 18072.

(7) Kanvah, S.; Joseph, J.; Schuster, G. B.; Barnett, R. N.; Cleveland, C. L.; Landman, U. Acc. Chem. Res. 2010, 43, 280.

(8) Genereux, J. C.; Barton, J. K. Chem. Rev. 2010, 110, 1642.

(9) Kawai, K.; Hayashi, M.; Majima, T. J. Am. Chem. Soc. 2012, 134, 4806.

(10) Porath, D.; Bezryadin, A.; de Vries, S.; Dekker, C. Nature 2000, 403, 635.

(11) Okamoto, A.; Tanaka, K.; Saito, I. J. Am. Chem. Soc. 2003, 125, 5066.

(12) Cohen, H.; Nogues, C.; Naaman, R.; Porath, D. Proc. Natl. Acad. Sci. U.S.A. 2005, 102, 12589.

(13) Hihath, J.; Xu, B.; Zhang, P.; Tao, N. Proc. Natl. Acad. Sci. U.S.A. 2005, 102, 16979.

(14) Taniguchi, M.; Kawai, T. Physica E 2006, 33, 1.

(15) Guo, X.; Gorodetsky, A. A.; Hone, J.; Barton, J. K.; Nuckoll, C. Nat. Nanotechnol. 2008, 3, 163.

(16) Huang, Y. C.; Sen, D. J. Am. Chem. Soc. 2010, 132, 2663.

(17) Ge, B.; Huang, Y. C.; Sen, D.; Yu, H. -Z. Angew. Chem. Int. Ed. 2010, 49, 9965.

(18) Slinker, J. D.; Muren, N. B.; Renfrew, S. E.; Barton, J. K. Nat. Chem. 2011, 3, 230. 
(19) Nakatani, K.; Dohno, C.; Saito, I. J. Am. Chem. Soc. 2002, 124, 6802.

(20) Dohno, C.; Nakatani, K.; Saito, I. J. Am. Chem. Soc. 2002, 124, 14580.

(21) Tashiro, R.; Sugiyama, H. J. Am. Chem. Soc. 2003, 125, 15282.

(22) Rajski, S. R.; Kumar, S.; Roberts, R. J.; Barton, J. K. J. Am. Chem. Soc. 1999, 121, 5615.

(23) Rajski, S. R.; Barton, J. K. Biochemistry 2001, 40, 5556.

(24) Wagenknecht, H. A.; Rajski, S. R.; Pascaly, M.; Stemp, E. D. A.; Barton, J. K. J. Am. Chem. Soc. 2001, 123, 4400.

(25) Nakatani, K.; Dohno, C.; Ogawa, A.; Saito, I. Chem. Biol. 2002, 9, 361.

(26) Fahlman, R. P.; Sen, D. J. Am. Chem. Soc. 2002, 124, 4610.

(27) Moser, H. E.; Dervan, P. B. Science 1987, 238, 645.

(28) Strobel, S.; Dervan, P. B. Science 1990, 249, 73.

(29) Greenberg, W.; Dervan, P. B. J. Am. Chem. Soc. 1995, 117, 5016.

(30) Best, G. C.; Dervan, P. B. J. Am. Chem. Soc. 1995, 117, 1187.

(31) Kan, Y., Schuster, G. B. J. Am. Chem. Soc. 1999, 121, 11607.

(32) Núñez, M. E., Noyes, K. T., Gianolio, D. A. McLaughln, L. W., Barton, J. K. Biochemistry 2000, 39, 6190.

(33) Okamoto, A.; Tanabe, K.; Dohno C, Saito I. Bioorg. Med. Chem. 2002, 10, 713.

(34) Tanabe, K.; Iida, H.; Haruna, K.; Kamei, T.; Okamoto, A.; Nishimoto, S. J. Am. Chem. Soc. 2006, 128, 692.

(35) Haruna, K.; Iida, H.; Tanabe, K.; Nishimoto, S. Org. Biomol. Chem. 2008, 6, 1613.

(36) Schuster, G. B. Acc. Chem. Res. 2000, 33, 253.

(37) Saito, I.; Nakamura, T.; Nakatani, K.; Yoshioka, Y.; Yamaguchi, K.; Sugiyama, H. J. Am. Chem. Soc. 1998, 120, 12686.

(38) The quantified cleavage data were shown in Figure S1. See Supplementary data.

(39) Ly, D.; Kan, Y.; Armitage, B.; Schuster, G. B. J. Am. Chem. Soc. 1996, 118, 8747. 
(40) Burrows, C. J.; Muller, J. G. Chem. Rev. 1998, 98, 1109.

(41) Núñez, M. E.; Hall, D. B.; Barton, J. K. Chem. Biol. 1999, 6, 85. 
(A)

$(\mathrm{ON})$
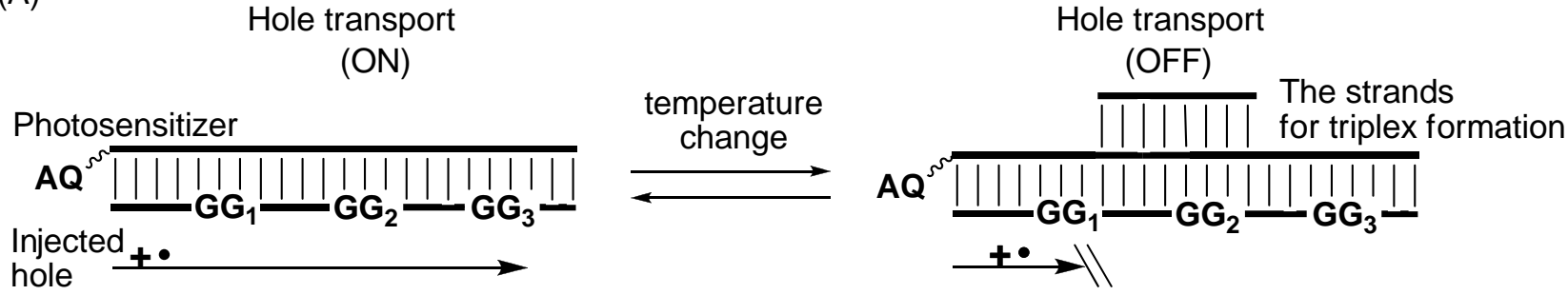

(B)

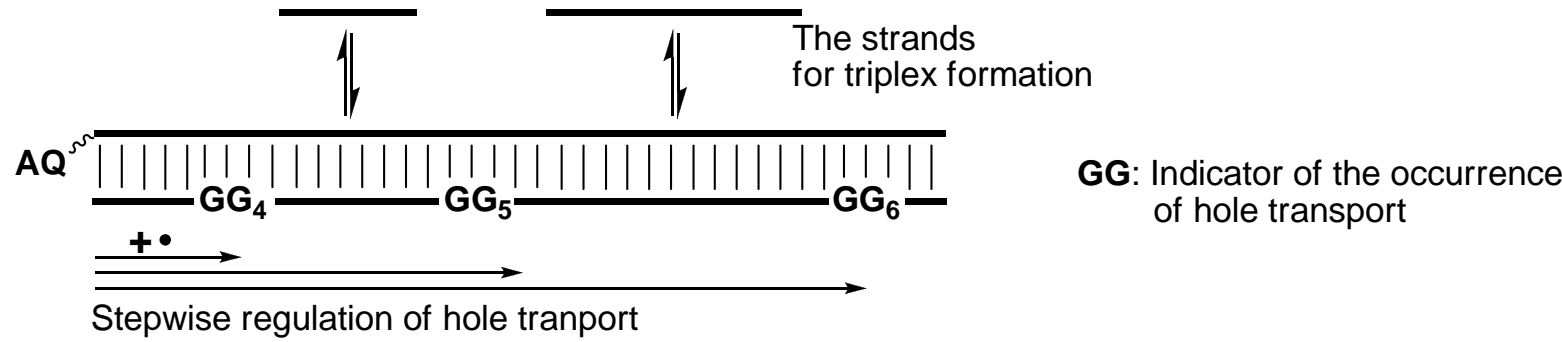

Figure 1. The protocol for reversible regulation of hole transport in DNA with a single triplex region (A), and dual triplex regions (B). The hole transport is suppressed by triplex formation and efficiently recovered by dissociation of triplex into duplex, as regulated by temperature change. 
ODN 1: 5'-TTTAGCC ATTCC TTCTACC TTGAT-3' ODN 2: 3'-AAATCGG ${ }_{1}$ TAAGG $_{2}$ AAGATGG $_{3}$ AACTA-5' $^{\prime}$ ODN 3: 5'-TTCC TTCT-3'

ODN 4: 5'-CCGCGCCA-3'

ODN 5: 5'-TTTAGCC ACTTCTCTACC TGATAGGTCTCTCTCTCTCTCTACC AGC-3' ODN 6: 3'-AAATCGG ${ }_{4}$ TGAAGAGATGG $_{5}$ ACTATCCAGAGAGAGAGAGAGATGG $_{6}$ TCG-5' $^{\prime}$ ODN 7:

ODN 8: $3^{\prime}-C T T C T C T-5^{\prime}$ 3'-TCTCTCTCTCTCTCT-5'

AQ-ODN X:

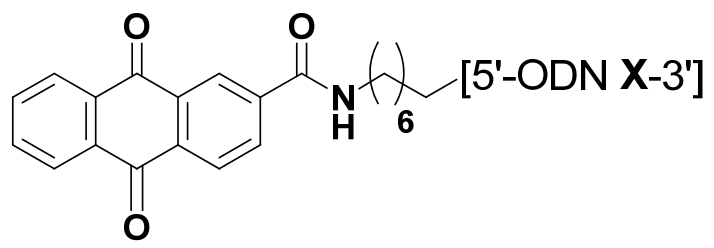

Duplex I: AQ-ODN 1/ODN 2

Triplex I: AQ-ODN 1/ODN 2/ODN 3
Duplex II: AQ-ODN 5/ODN 6

Triplex II: AQ-ODN 5/ODN 6/ODN 7/ODN 8 Triplex III: AQ-ODN 5/ODN 6/ODN 7

Triplex IV: AQ-ODN 5/ODN 6/ODN 8

Figure 2. Sequences and structure of the oligodeoxynucleotides (ODNs) used in this study. The bases arranged in the triplex region are shown in italics. 


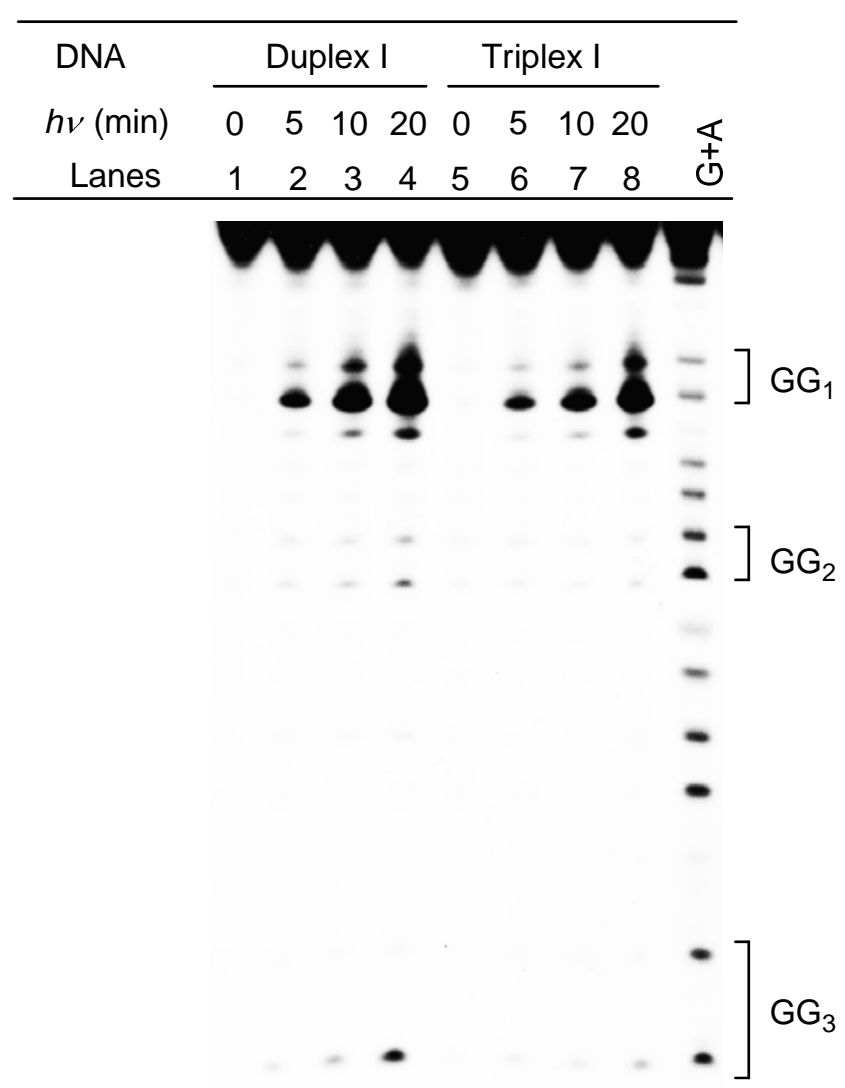

Figure 3. An autoradiogram of a denaturing sequencing gel for the Duplex I (AQ-ODN $1 /{ }^{32} \mathrm{P}$-end labeled ODN 2, lanes 1-4) and the the Triplex I (AQ-ODN $1 /{ }^{32} \mathrm{P}$-end labeled ODN 2/ODN 3, lanes 5-8) after photooxidation. The samples were photoirradiated at $365 \mathrm{~nm}$ in the presence of $2 \mathrm{mM}$ $\mathrm{MgCl}_{2}$ in sodium cacodylate buffer (pH 5.5) at $0{ }^{\circ} \mathrm{C}$ for 0 (lanes 1 and 5), 5 (lanes 2 and 6), 10 (lanes 3 and 7) and 20 min (lanes 4 and 8) followed by hot piperidine treatment $\left(90{ }^{\circ} \mathrm{C}, 20 \mathrm{~min}\right.$ ). The lane labeled $\mathrm{G}+\mathrm{A}$ is Maxam-Gilbert sequencing lane. 
(A)

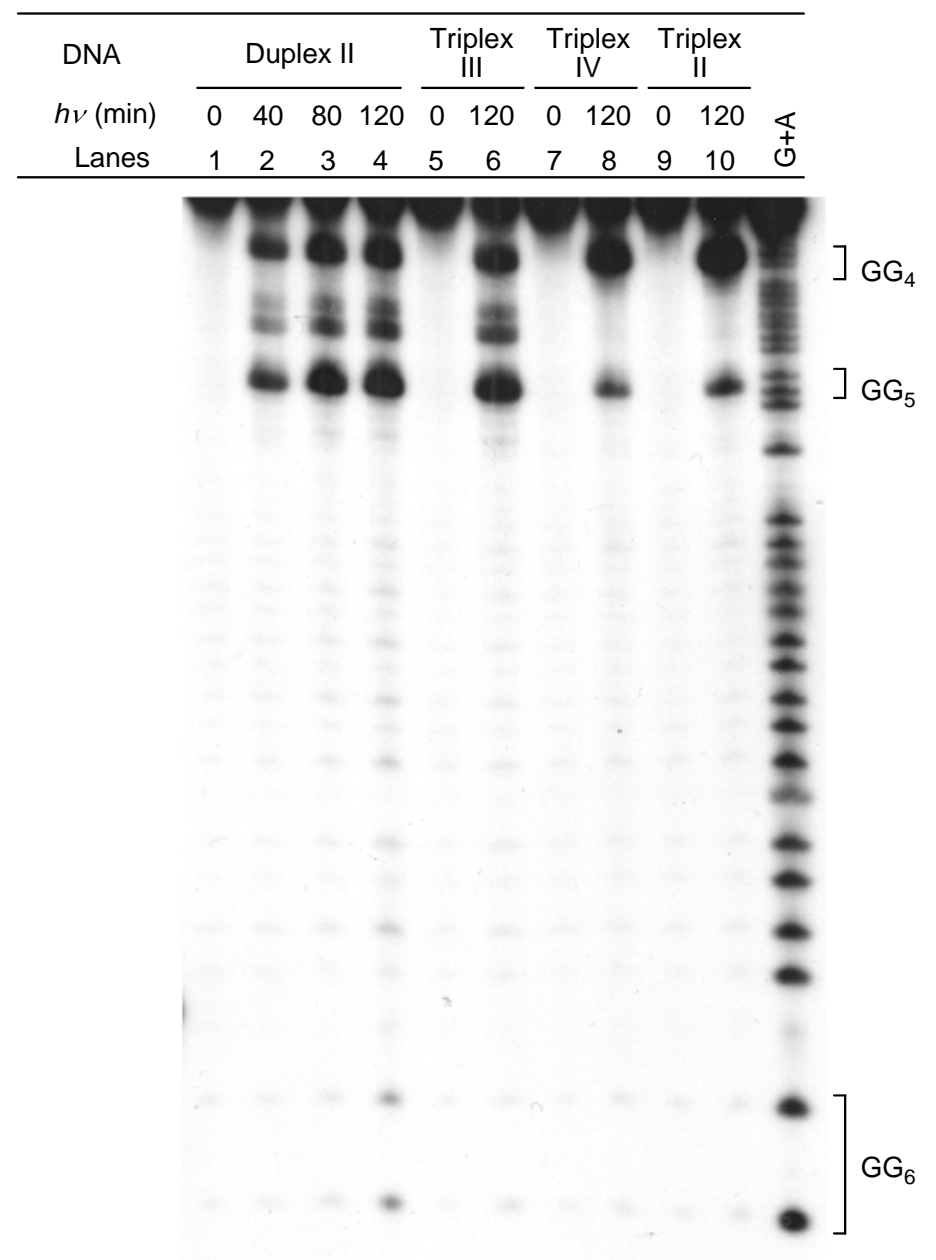

(B)
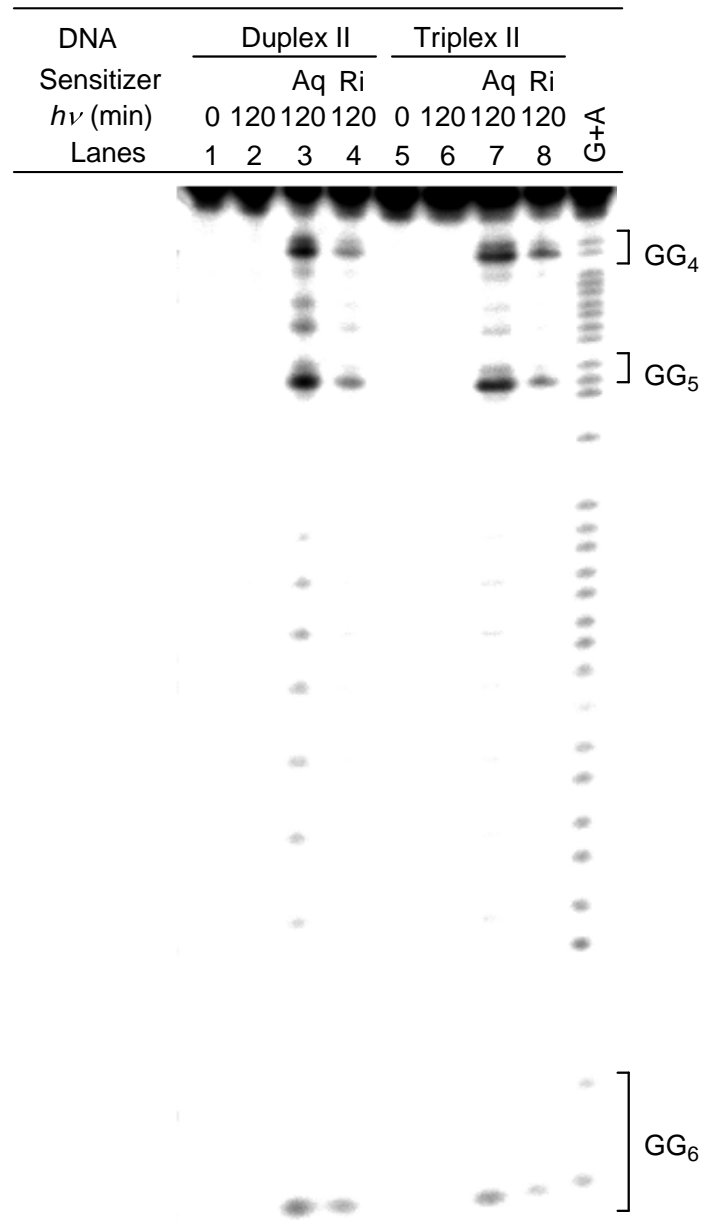

Figure 4. Autoradiogram of a denaturing gel electrophoresis for Duplex II, Triplex II, Triplex III, and Triplex IV after photooxidation. (A) The Duplex II (lanes 1-4), Triplex II (lanes 9, 10), Triplex III (lanes 5, 6) and Triplex IV (lanes 7, 8) were photoirradiated at $365 \mathrm{~nm}$ in the presence of $2 \mathrm{mM} \mathrm{MgCl}_{2}$ in sodium cacodylate buffer (pH 5.5) at $0{ }^{\circ} \mathrm{C}$ for 0 (lanes 1, 5, 7, and 9), $40 \mathrm{~min}$ (lanes 2), $80 \mathrm{~min}$ (lanes 3) and $120 \mathrm{~min}$ (lanes 4, 6, 8, and 10) followed by hot piperidine treatment $\left(90{ }^{\circ} \mathrm{C}, 20 \mathrm{~min}\right.$ ). The lane labeled $\mathrm{G}+\mathrm{A}$ is Maxam-Gilbert sequencing lane. (B) Duplex II (lanes 1-4) and Triplex II (lanes 5-8) were photoirradiated in the presence or absence of 9,10-anthraquinone (Aq: $1 \mu \mathrm{M}$ ) or riboflavin (Ri: $4.8 \mu \mathrm{M}$ ) in sodium cacodylate buffer ( $\mathrm{pH}$ 5.5) containing $2 \mathrm{mM} \mathrm{MgCl}_{2}$ at $0{ }^{\circ} \mathrm{C}$ for $120 \mathrm{~min}$. After photoirradiation, the samples were treated with piperidine at $90{ }^{\circ} \mathrm{C}$ for $20 \mathrm{~min}$. Lane 1 and 5, dark control in the presence of Aq; lane 2 and 6, irradiation in the absence of photosensitizers; lane 3 and 7, irradiation in the presence of Aq; lane 4 and 8, irradiation in the presence of $\mathrm{Ri}$. The lane labeled $\mathrm{G}+\mathrm{A}$ is Maxam-Gilbert sequencing lane. 
(A)

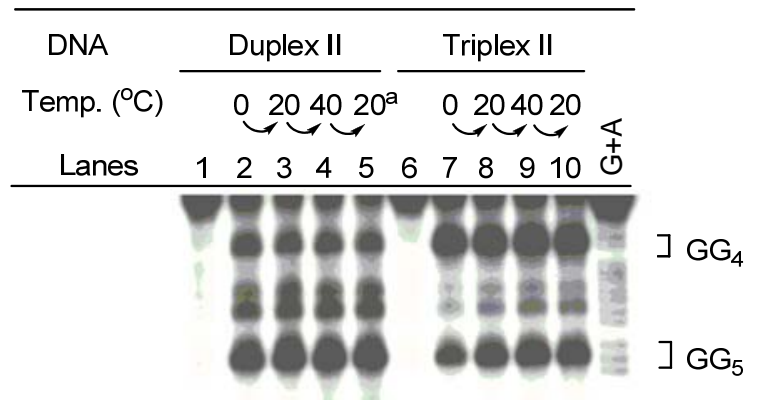

(B)

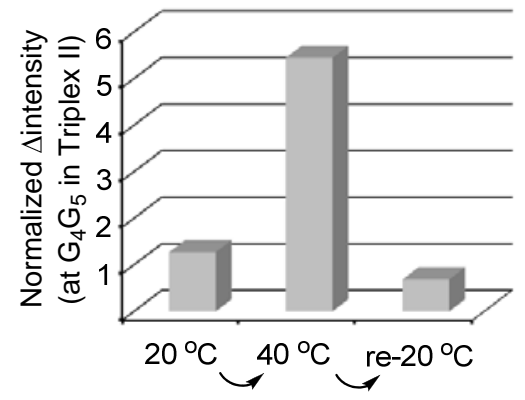

Figure 5. (A) Autoradiogram of a denaturing gel electrophoresis for ${ }^{32} \mathrm{P}-5$ '-end labeled ODN 6 after photooxidation of the Duplex II (AQ-ODN 5/ODN 6, lanes 1-5) and Triplex II (AQ-ODN 5/ODN 6/ODN 7/ODN 8, lanes 6-10). The reaction vessels containing each DNA strands were transferred into the water bathes maintained at 0 (lanes 2 and 7), 20 (lanes 3 and 8) and $40{ }^{\circ} \mathrm{C}$ (lanes 4 and 9) in sequence. Then, the vessels were transferred into the water bath at $20{ }^{\circ} \mathrm{C}$ (lanes 5 and 10), again. The samples were irradiated at $365 \mathrm{~nm}$ for $5 \mathrm{~min}$ at each temperature. After photoirradiation, small aliquots were removed to analyze photooxidation of helices by hot piperidine treatment. Lanes 1 , dark control; lane 2 and 7, irradiation at $0{ }^{\circ} \mathrm{C}$; lane 3 and 8, irradiation of the sample at $0{ }^{\circ} \mathrm{C}$ and then $20{ }^{\circ} \mathrm{C}$; lane 4 and 9, irradiation of the sample at 0 and $20{ }^{\circ} \mathrm{C}$ and then $40{ }^{\circ} \mathrm{C}$.; lane 5 and 10 , irradiation of the sample at 0,20 , and $40{ }^{\circ} \mathrm{C}$ and then $20{ }^{\circ} \mathrm{C}$. (B) The increments of cleavage intensity at $\mathrm{GG}_{6}$ based on densitometry analysis of Figure $5 \mathrm{~A}$. Each $\Delta$ intensity were obtained as follows. $\Delta$ Intensity at $\mathrm{GG}_{6}\left(20^{\circ} \mathrm{C}\right)=$ cleavage intensity at $\mathrm{GG}_{6}$ obtained from lane 8 in Figure $5 \mathrm{~A}$ $\left(20{ }^{\circ} \mathrm{C}\right)$ - intensity obtained from lane $7\left(0{ }^{\circ} \mathrm{C}\right)$. $\Delta$ intensity at $\mathrm{GG}_{6}\left(40{ }^{\circ} \mathrm{C}\right)=$ intensity obtained from lane $9\left(40{ }^{\circ} \mathrm{C}\right)$ - intensity obtained from lane $8\left(20{ }^{\circ} \mathrm{C}\right)$. $\Delta$ intensity at $\mathrm{GG}_{6}\left(\right.$ re $\left.-20{ }^{\circ} \mathrm{C}\right)=$ intensity obtained from lane 10 (re-cooled, $20{ }^{\circ} \mathrm{C}$ ) - intensity obtained from lane $9\left(40{ }^{\circ} \mathrm{C}\right)$. 
